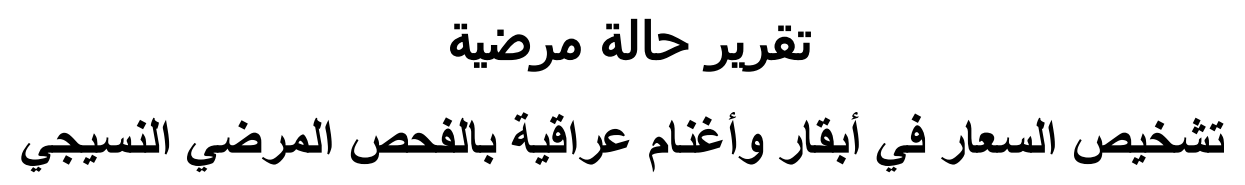

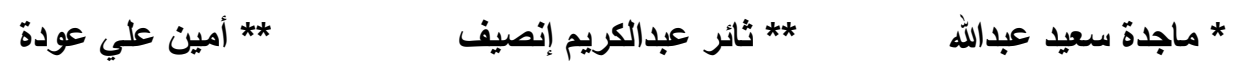

$$
\begin{aligned}
& \text { * وزارة الزراعة ـ الثركة العامة للبيطرة ـ قسم المختبرات و البحوث ـ شعبة التثخيص المرضي النسيجي. } \\
& \text { ** وزارة الزراعة ـ الثركة العامة للبيطرة ـ المستثفى البيطري - بغداد ـ العراق }
\end{aligned}
$$

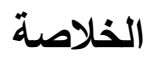

تم التشخيص المختبري للسعار في العراق بإتباع طرق التشخيص المرضي النسجي لأول

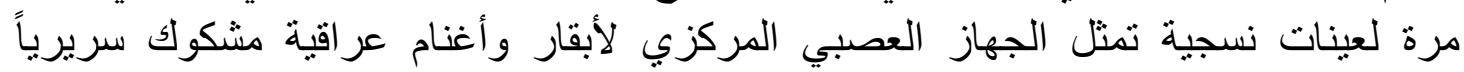

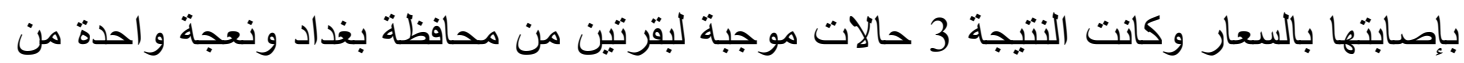

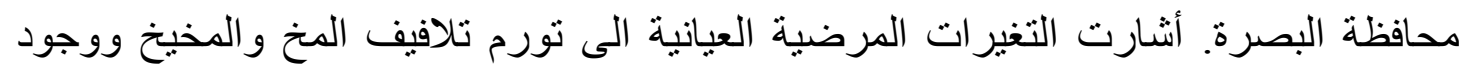

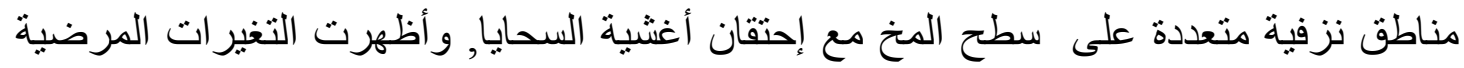

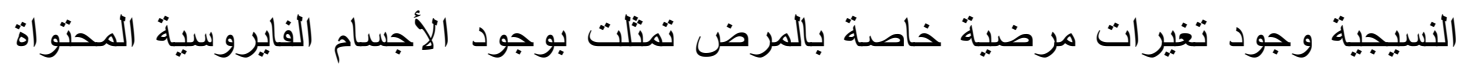

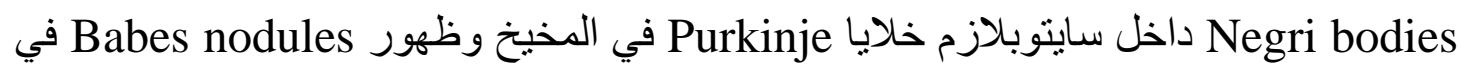

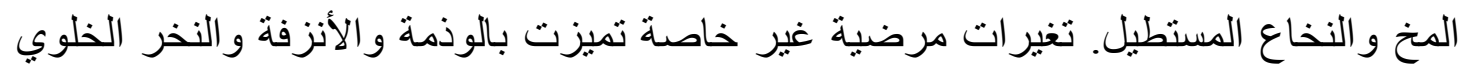

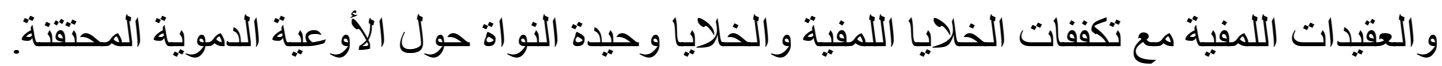

\title{
Case report: Histopathological Diagnosis of Rabies in Iraqi Cows and Ewes
}

Accepted on 29/5/2011

\section{Summary}

Rabies was diagnosed (for the first time) in clinically suspected rabid Iraqi cows and ewes by using histopathological methods. The result showed 3 positive cases 2 cows from Baghdad governorate and $\mathbf{1}$ ewe from Al - Basra governorate. The gross pathological changes included swelling of cerebrum and cerebellum, multiple hemorrhagic spots within cerebral parenchyma, and sever congestion in meningial blood vessels. The histopathological changes showed specific changes represented by Negri bodies as intracytoplasmic inclusions within Purkinje cells in cerebellum and Babes nodules in cerebrum and medulla oblongata. Non specific changes included edema, hemorrhages, cellular necrosis, lymphocytic foci and lymphocytic and mononuclear cuffing surrounding congested blood vessels.

Keywords: Rhabies, ewe, cow, histopathology. 


\section{المقدمة}

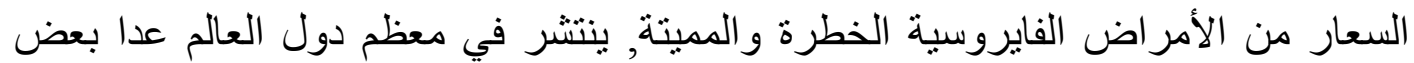

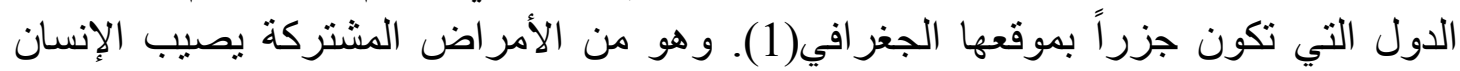

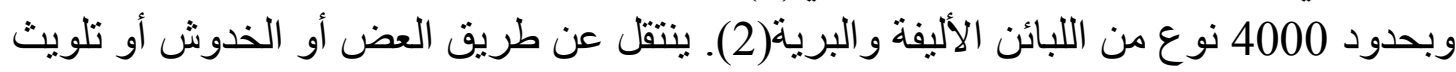

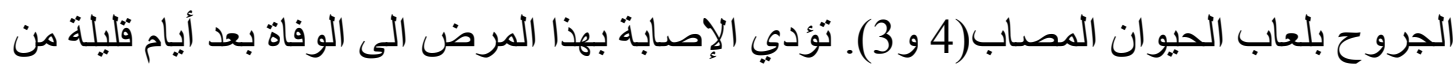

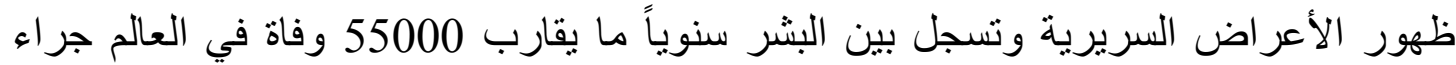

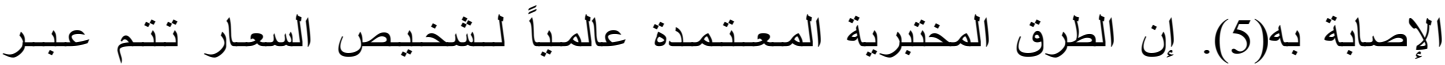

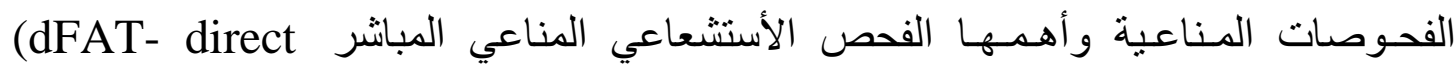
Fluorescent Antibody technique) (Immunohistochemistry tests)

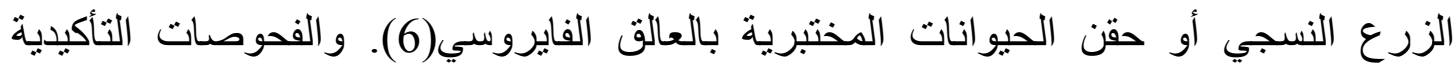
الحديثة مثل RT - PCR (7). أما بالنسبة للتشخيص المرضي النسجي فيعطي دلائل تشخيصية

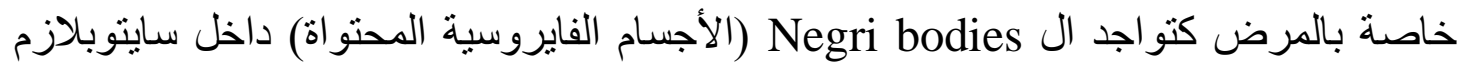

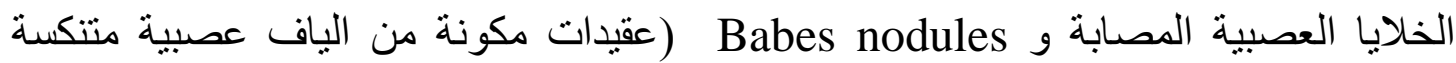

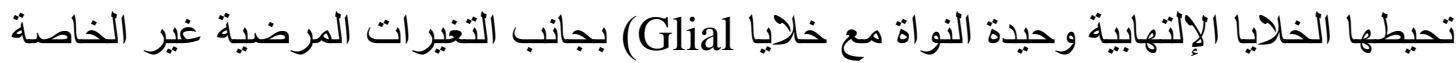

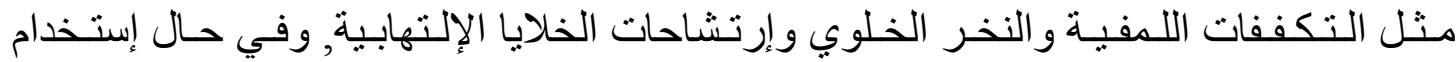

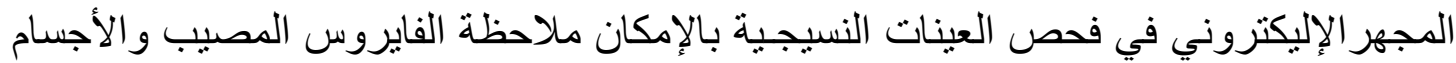

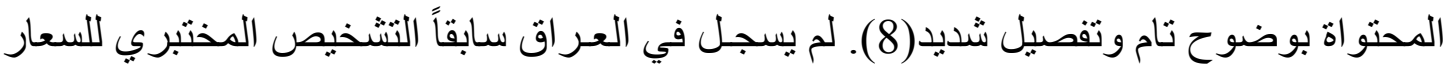

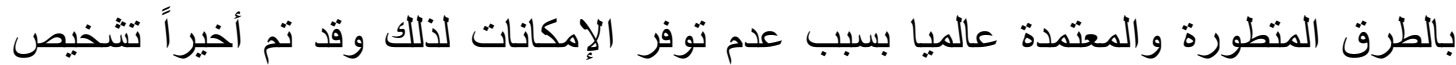

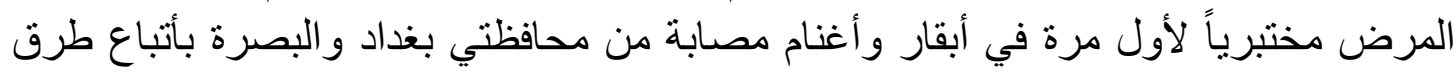

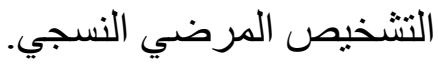

\section{المواد و طر ائق العمل}

الجهاز العصبي المركزي ( المخ والمخيخ والنخاع المستطيل) لبقرتين من محافظة

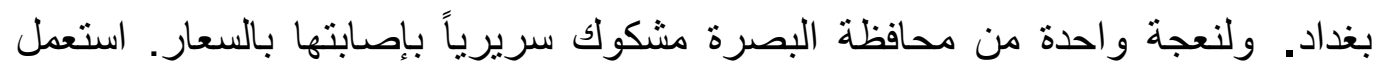

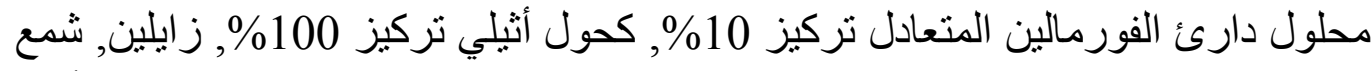
البر افين, الصبغة الروتينية Hematoxylin and Eosin

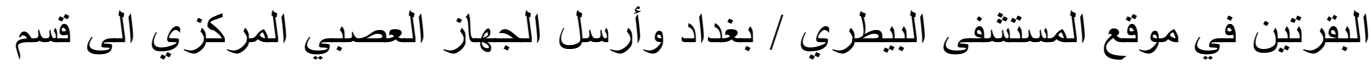

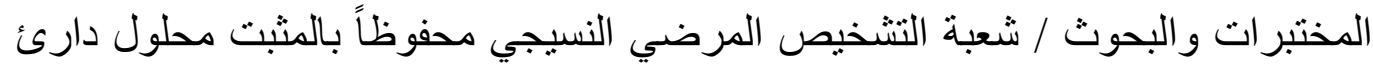

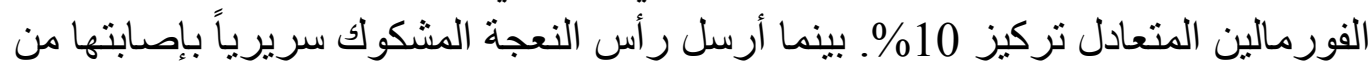

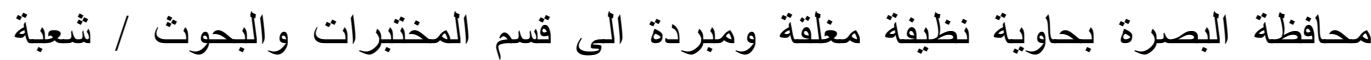

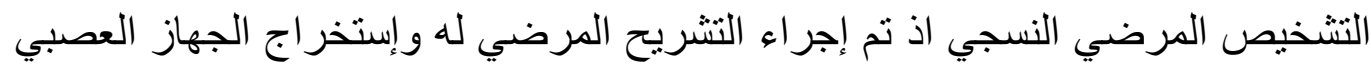

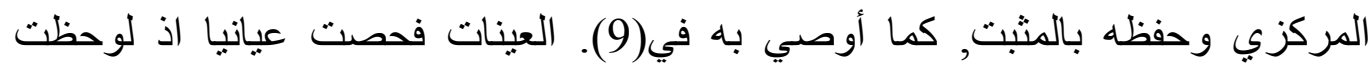

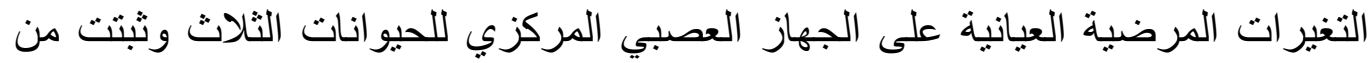
حيث الثكل و الحجم و اللون و المكونات و التوزئ التوزيع. 
قطعت عينات نسجية من المخ والمخيخ والنخاع المستطيل بأبعاد 1 cm 1 1 وحفظت ف \& E في محلول دارئ الفور مالين المتعادل تركيز 10\% وصنبخت بالصبغة الروتينية وبحسب طريقة مبل فرئ Harris 's Hematoxylin).

\section{التنائجج}

التغيرات المرضية العيانية: للجهاز العصبي المركزي في البقرتين اذ لوحظ تورم تلافيف

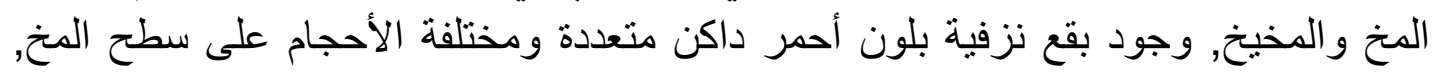

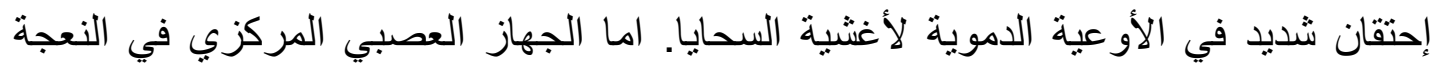

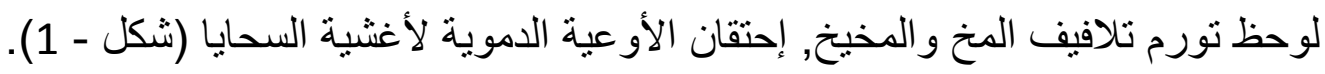

التغير ات المرضية النسيجية: للجهاز العصبي المركزي في البقرتين في المخيخ، تنكس وتنخر

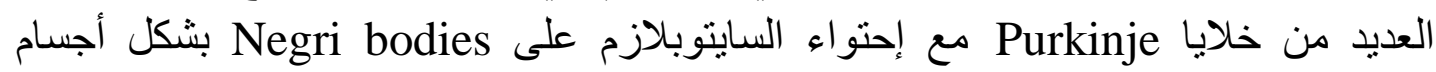

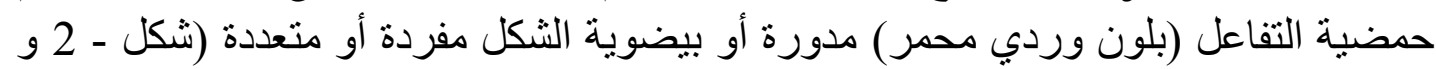

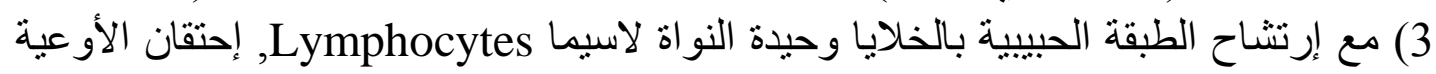

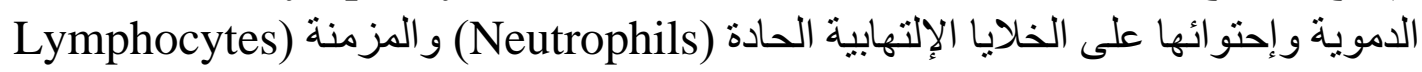

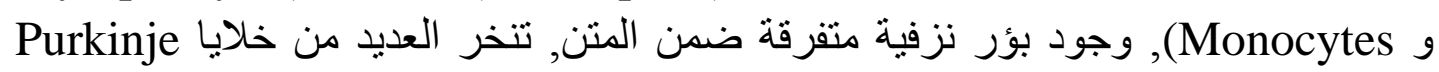

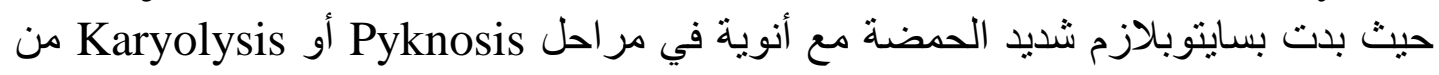

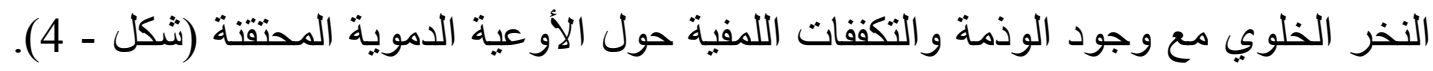

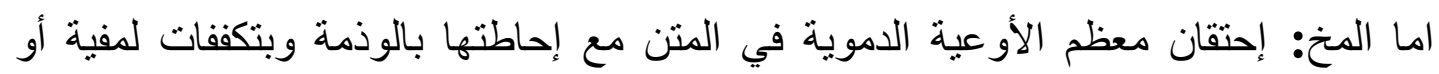

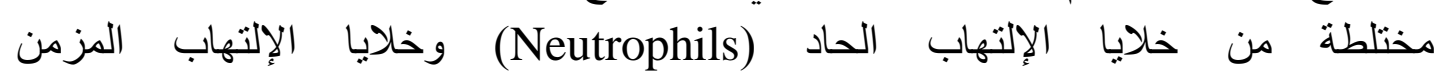
Babes (macrophages, Lymphocytes, plasma cells) بشكل عقيدات أو نر اكيب نسجية مكونة من ألياف عصبية متنخرة ومحاطة بالخلايا

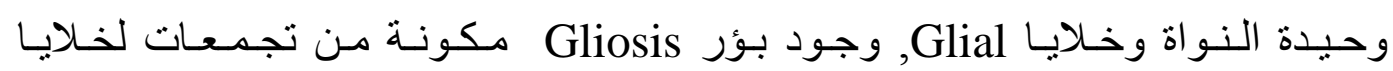
Glial المزمنة.

النخاع المستطيل: إحتقان معظم الأوعية الدموية وإحاطتها بالوذمة وبالتكففات اللمفية (شكل

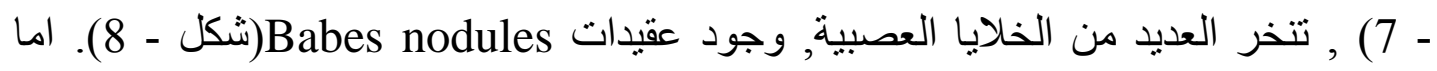
أغثية السحايا: إحتقان الأوعية الدموية وإحتو ائها على الخلايا الإلتهابية مع إحاطتها بتكففات

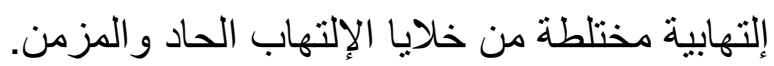

الجهاز العصبي المركزي في النعجة: في المخيخ لوحظ تغير ات مرضية تنخرية وتنكسية

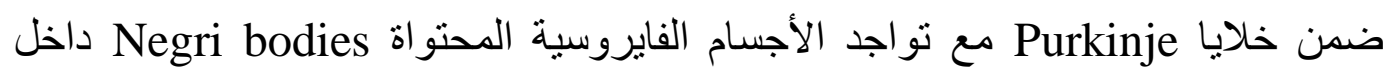

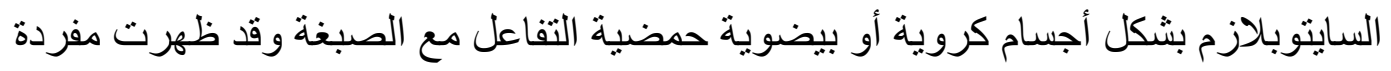

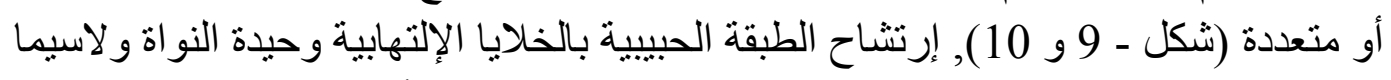
lymphocytes

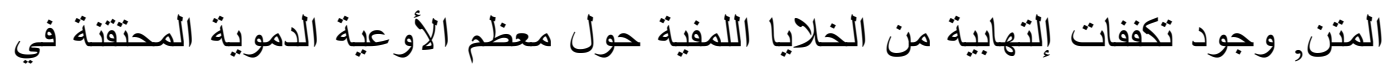


النخاع المستطيل: تنكس وتنخر العديد من الخلايا العصبية النجمية, وجود تغيرات

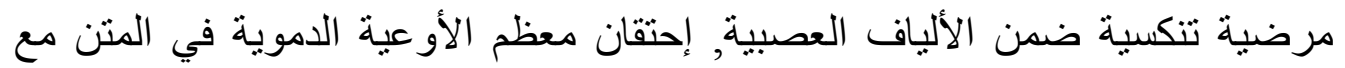

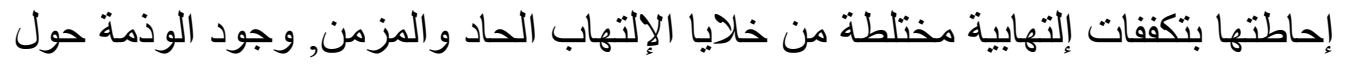
العصبات و الأوعية الدموية المحتقنة. اما أغثية السحايا فقد لوحظ إحتقان الإناب الأوعية

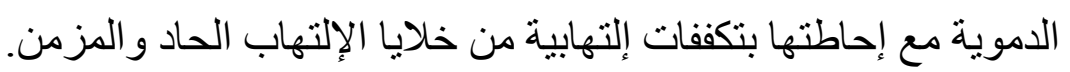

\section{المناقثة}

السعار مرض مشترك ومميت وو اسع الأنتشار في العالم لذلك تتطلب عملية تشخيصه مختبرياً

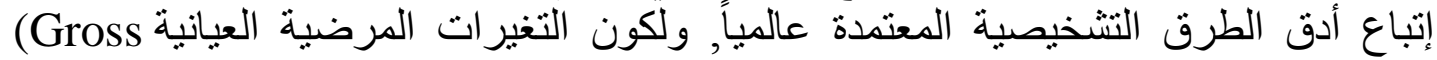
pathological changes) على الفحوصات المختبرية, وأن العينات المرضية الازمة لتشخيص الإصنة المرض تؤخذ من الجهاز العصبي المركزي(11). يعد فحص

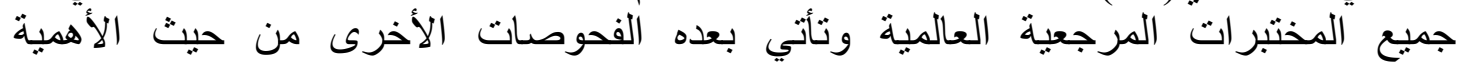

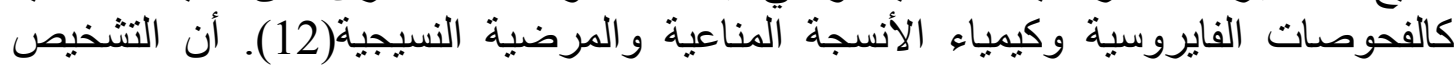

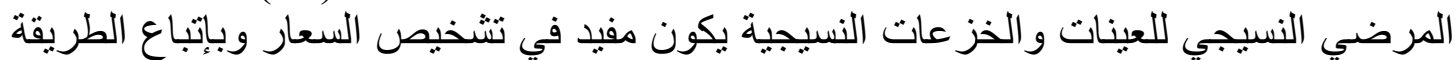

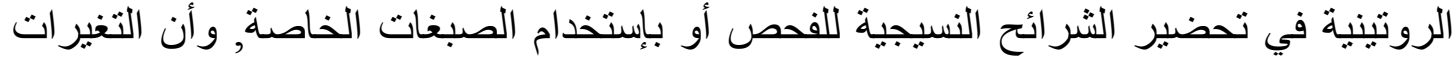

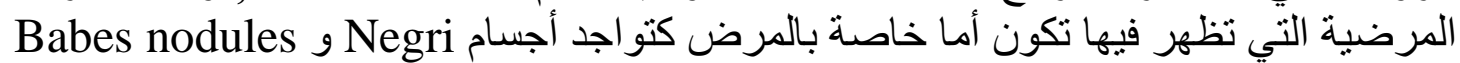
أو غير خاصة مثل Encephalomeningitis(13). لكن هذه الطريقة غير مثالية للتشخيص

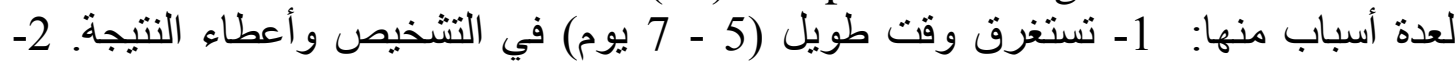
50 من الحالات قد لاتعطي Negri bodies لاسيما في بداية الإصابة. 3- لاتفيد في العينات

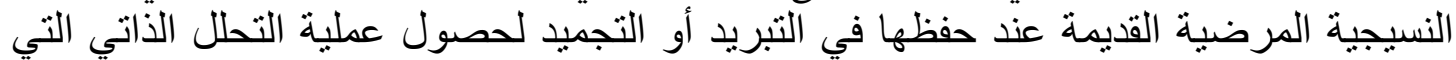

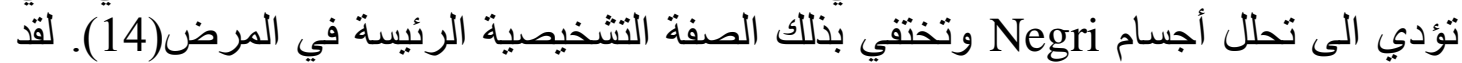

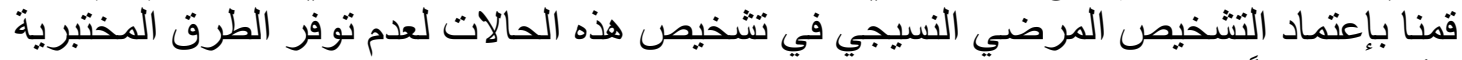

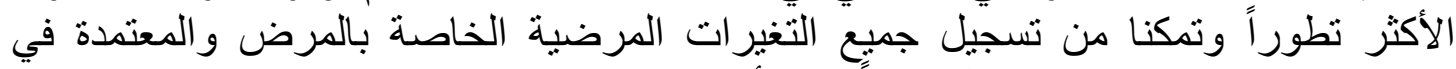

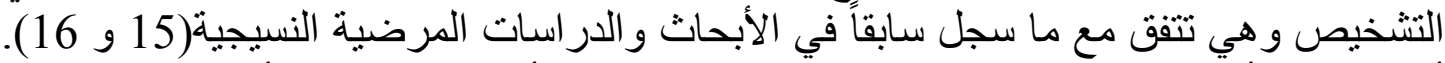

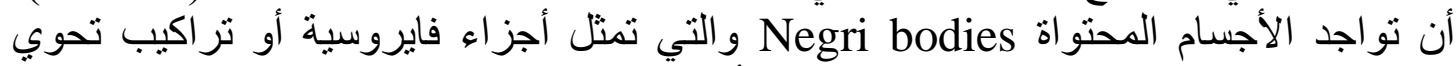
الحامض النووي الراييوزي (RNP) يعد من أهم العلامات التشخيصية منذ إكتشافها في بداية

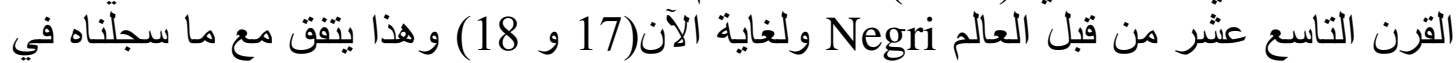
تشخيص هذه الحالات. كما أن ظهور الآفات المرضية النسيجية المسماة عقبدات

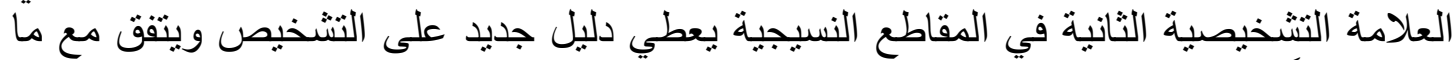

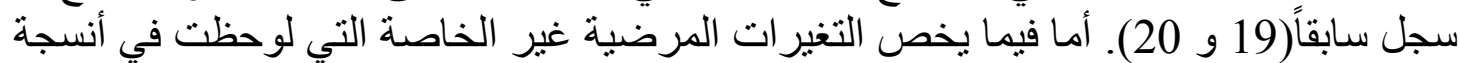

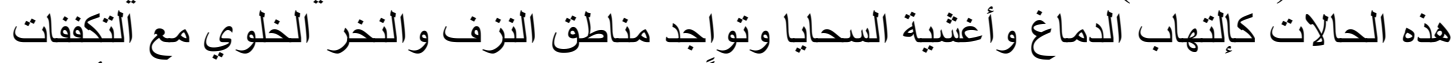

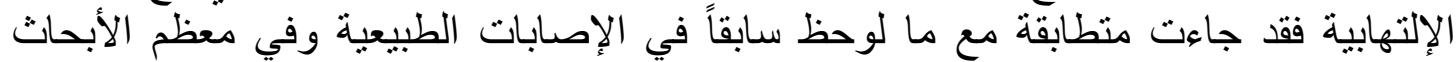

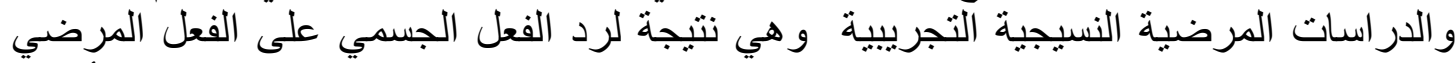

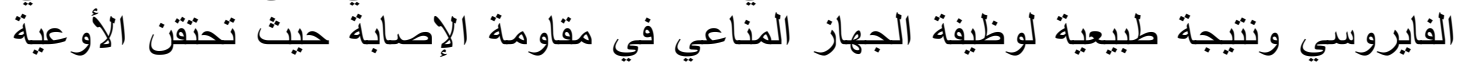

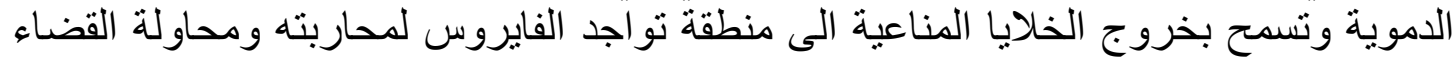

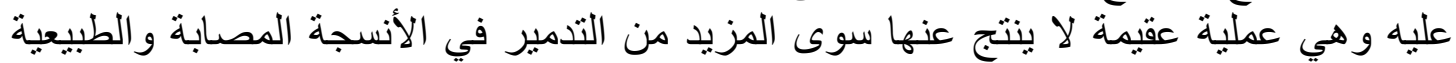
بفعل الأنزيمات وعو امل التحلل و المضادات الحياتية التي تحملها هذه الخلايا (21 - 22). 


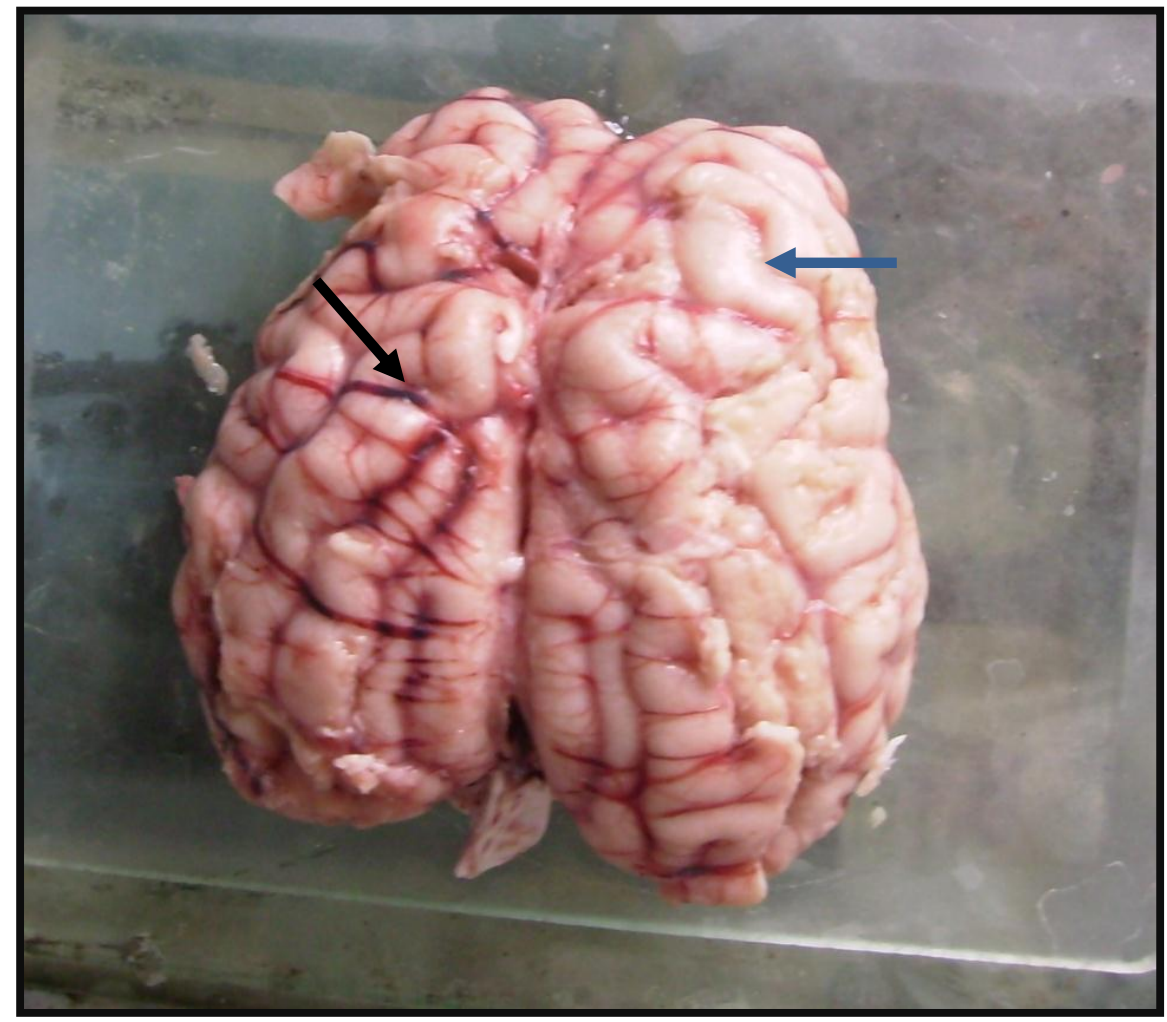

Figure - 1: Central nervous system of rabid ewe: notice swelling of cerebrum (巨) and congested meningial blood vessels ( $\bar{B})$.

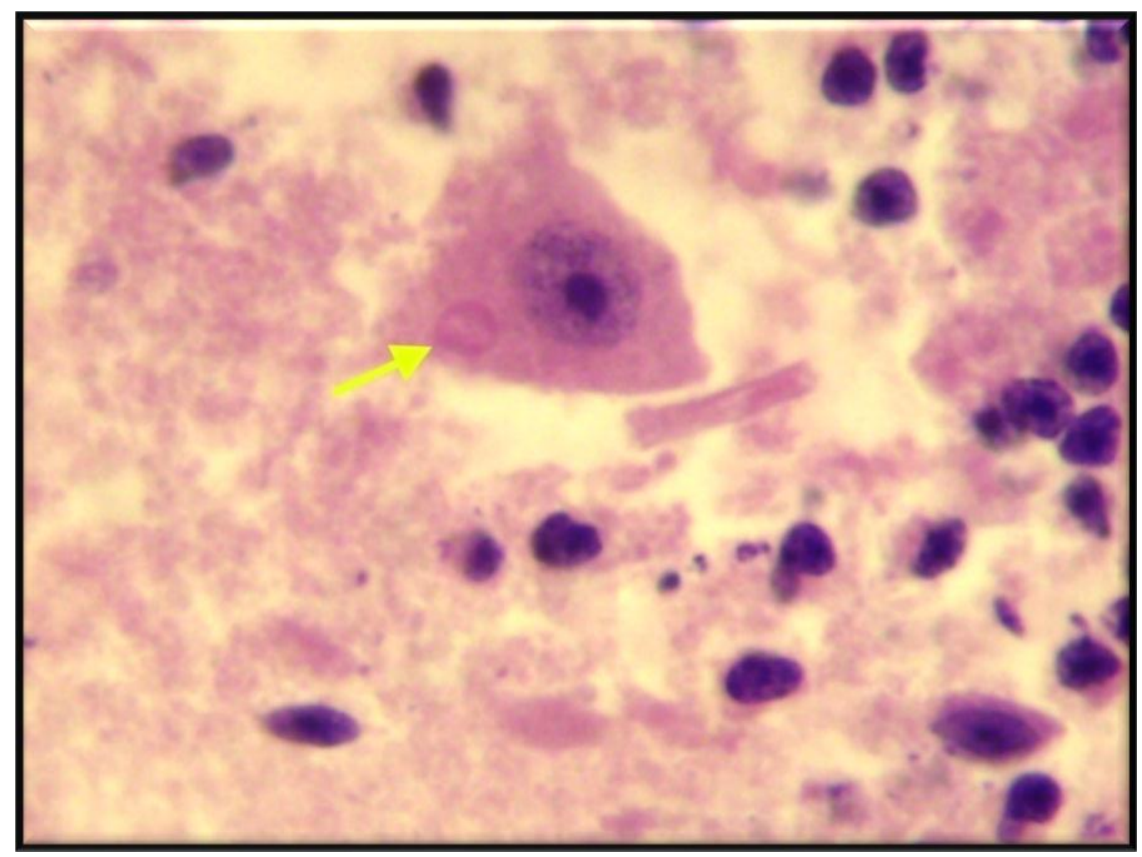

Figure - 2: Histopathological section in cerebellum of rabid cow showed the presence of round shaped, intracytoplasmic and acidophilic inclusion body (Negri body) in Purkinje cell (arrow) with mononuclear cell infiltration within granular layer. (H \& E stain X40). 


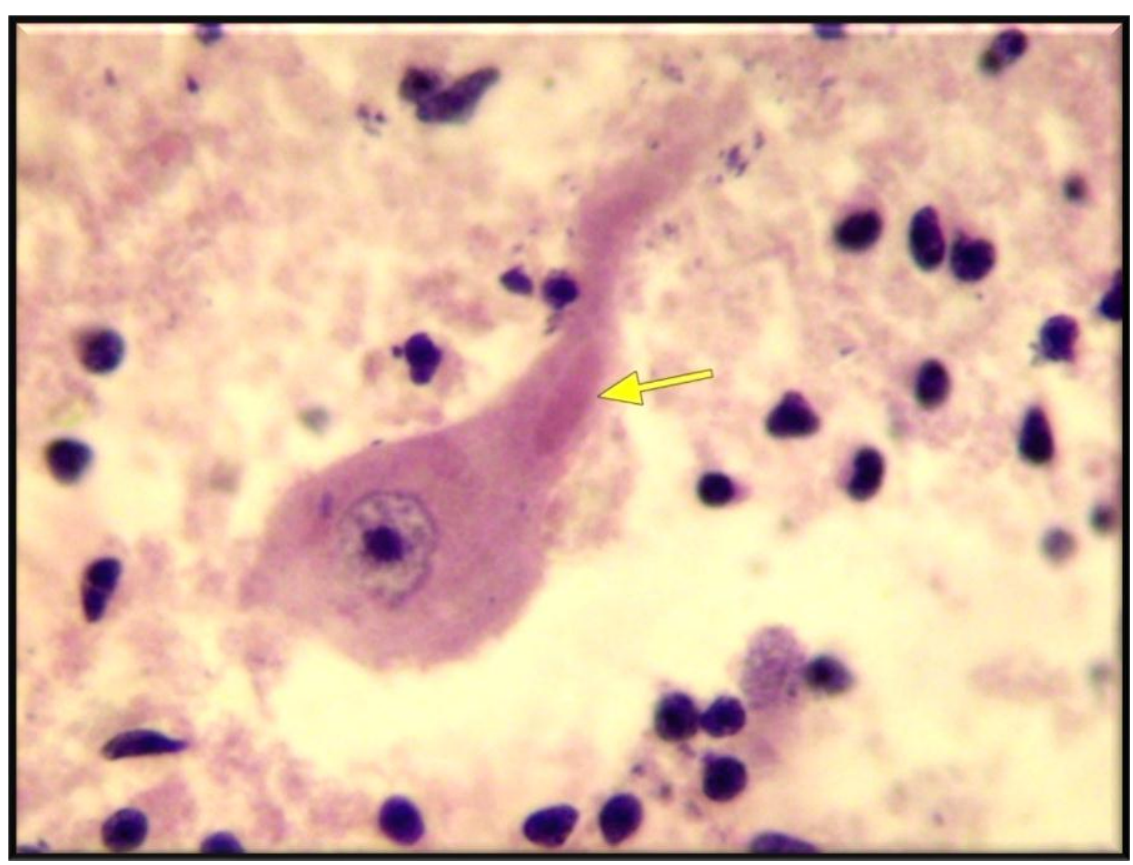

Figure - 3: Histopathological section in cerebellum of rabid cow showed the presence of oval shaped, intracytoplasmic and acidophilic inclusion body (Negri body) in Purkinje cell (arrow) with mononuclear cell infiltration within granular layer. (H \& E stain X40).

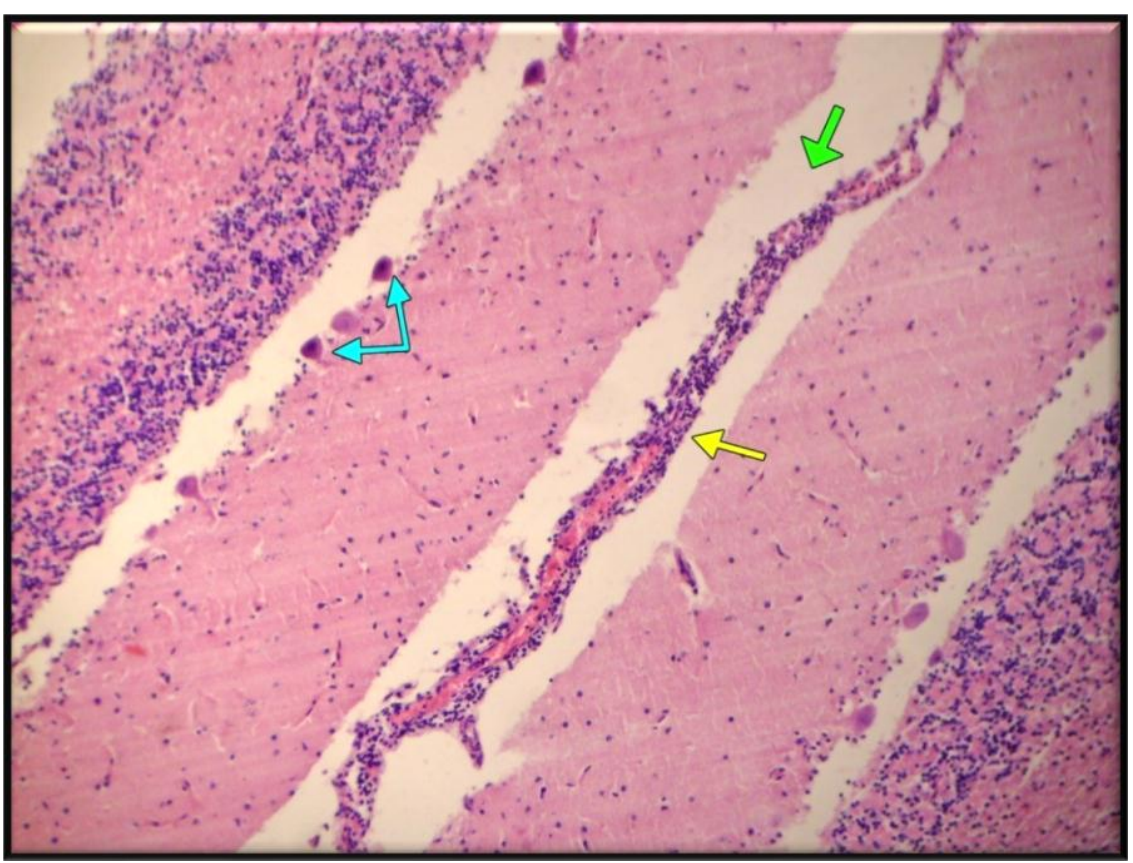

Figure - 4: Histopathological section in cerebellum of rabid cow showed perivascular lymphocytic cuffing ( ) and edema ( $(\overline{)})$ surrounding congested blood vessels with dead Purkinje cells characterized by pyknotic nuclei and acidophilic cytoplasm ( 巨 ). (H \& E stain X10). 


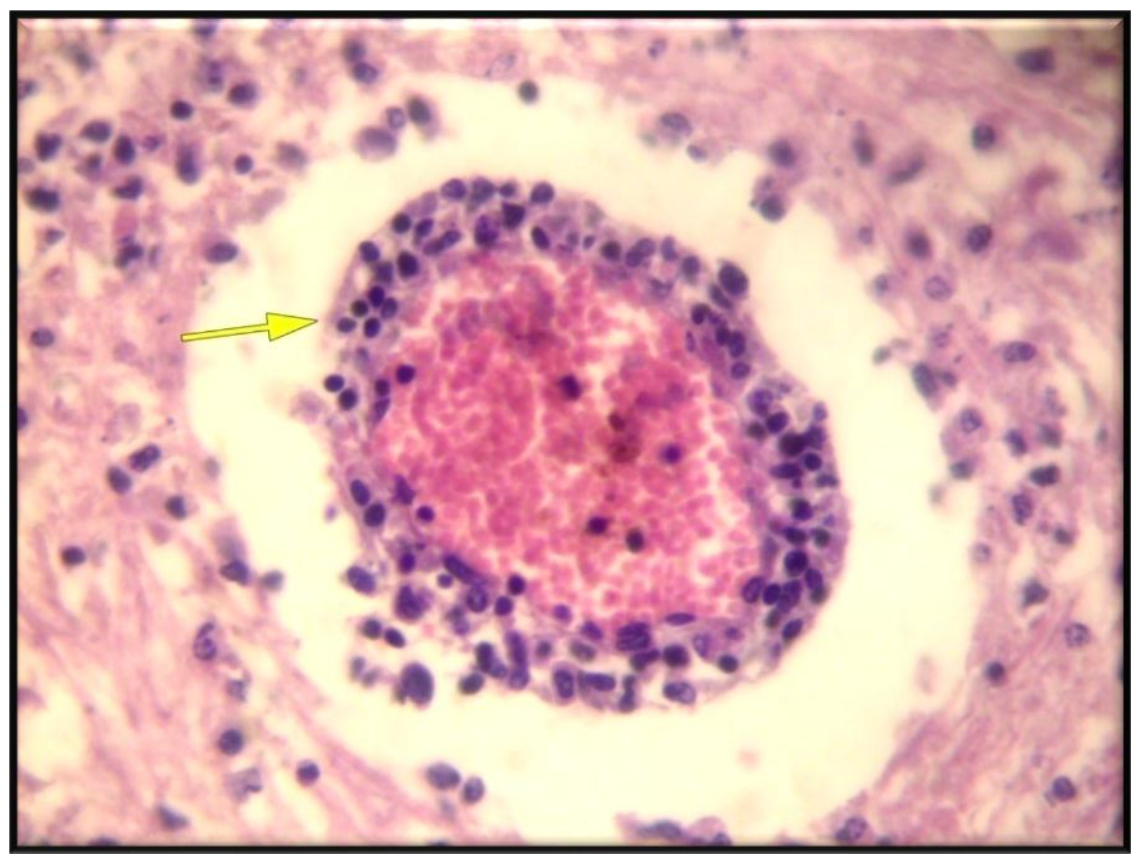

Figure - 5: Histopathological section in cerebrum of rabid cow showed congested blood vessel with perivascular mononuclear cuffing and edema (arrow). (H \& E stain X40).

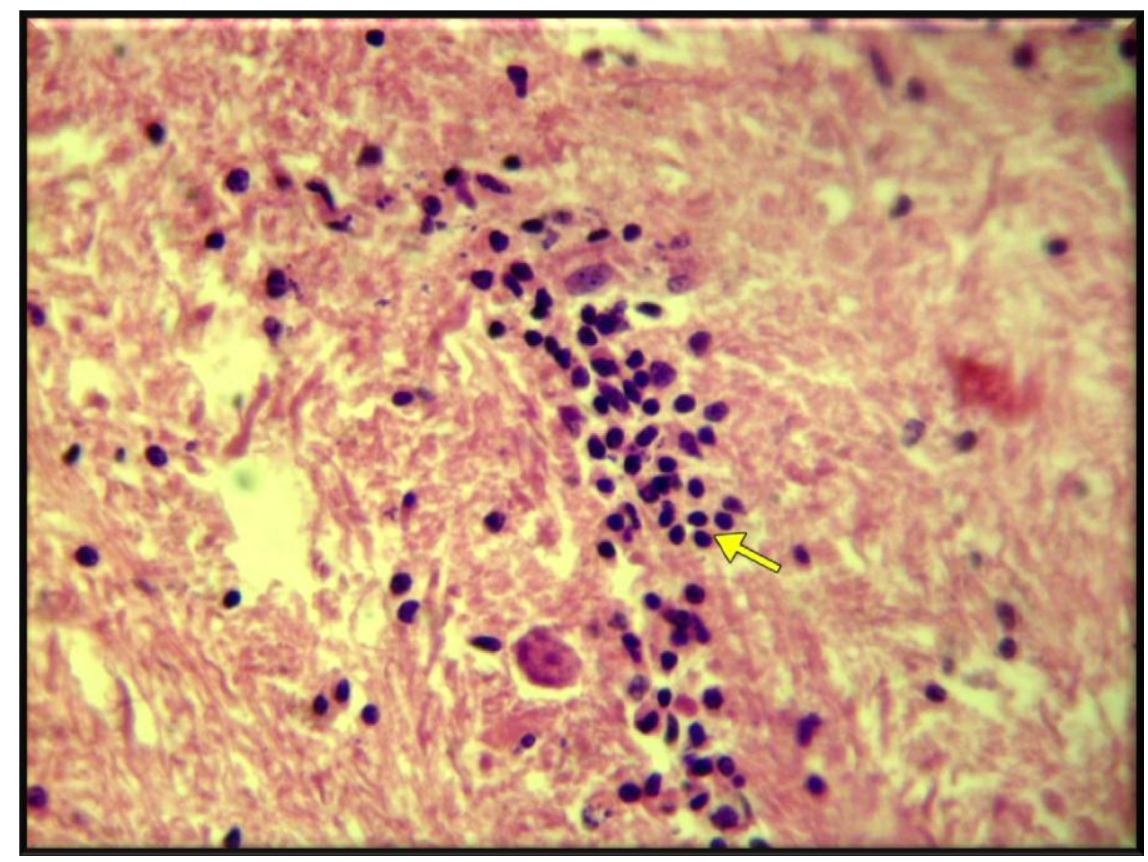

Figure - 6: Histopathological section in cerebrum of rabid cow showed aggregation of glial cells (gliosis) (arrow). (H \& E stain X40). 


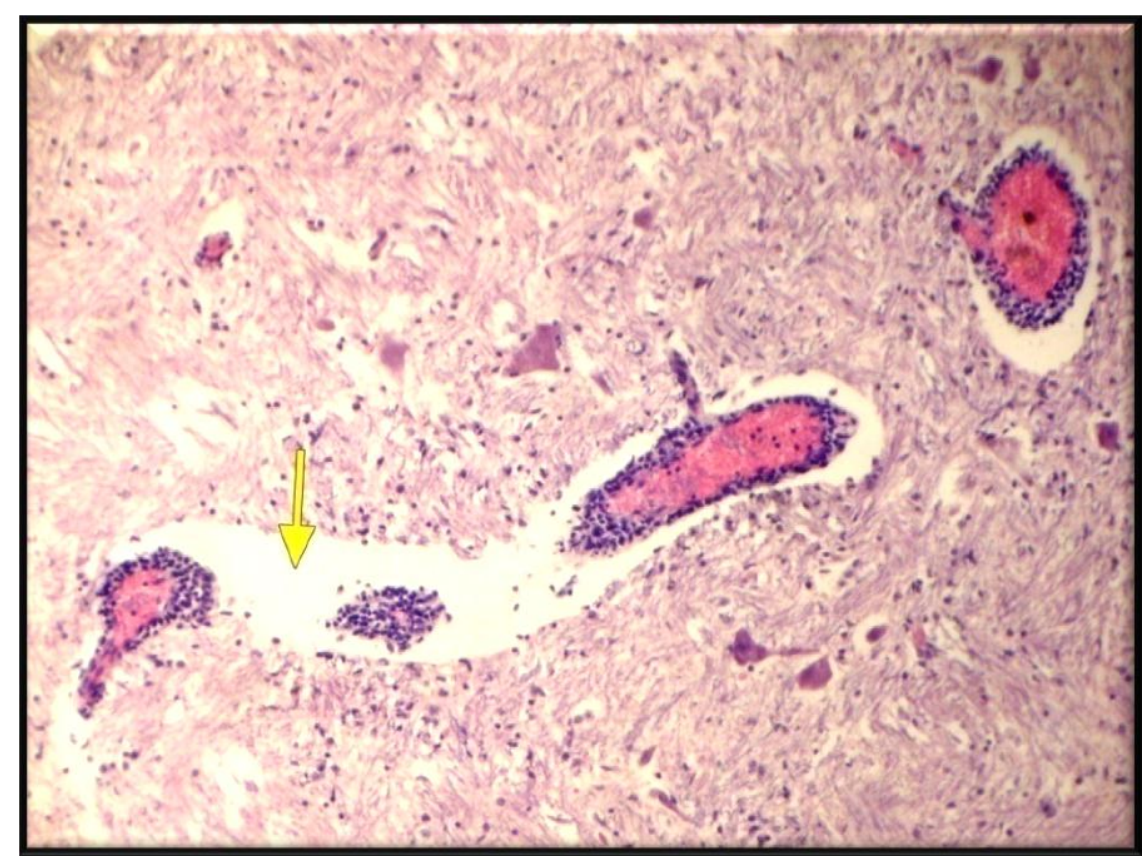

Figure - 7: Histopathological section in medulla oblongata of rabid cow showed congested blood vessels with perivascular mononuclear cuffing and edema (arrow). (H \& E stain X10).

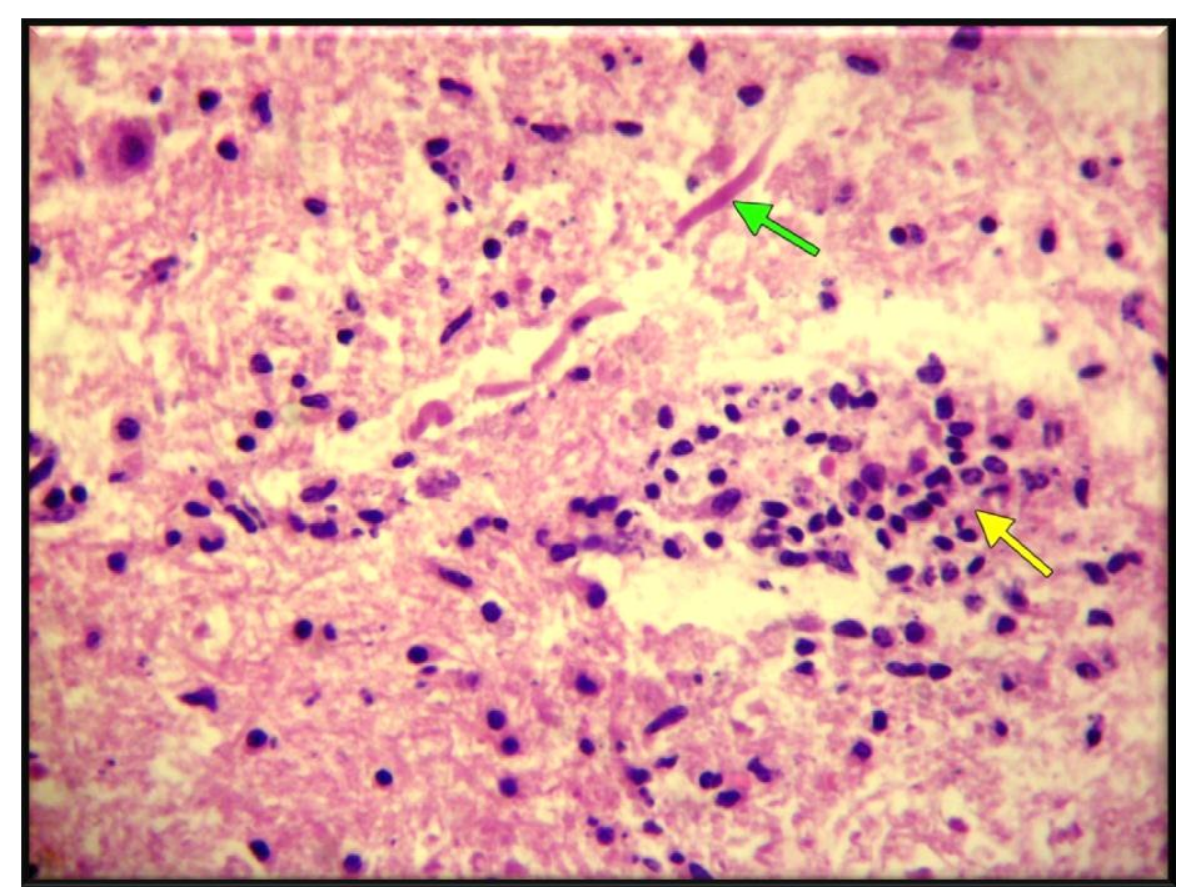

Figure - 8: Histopathological section in medulla oblongata of rabid cow showed Babes nodule which consisted of degenerated neurons $\longleftrightarrow$ ) surrounded by glial cells and mononuclear cells $\Leftrightarrow$ ). (H \& E stain X40). 


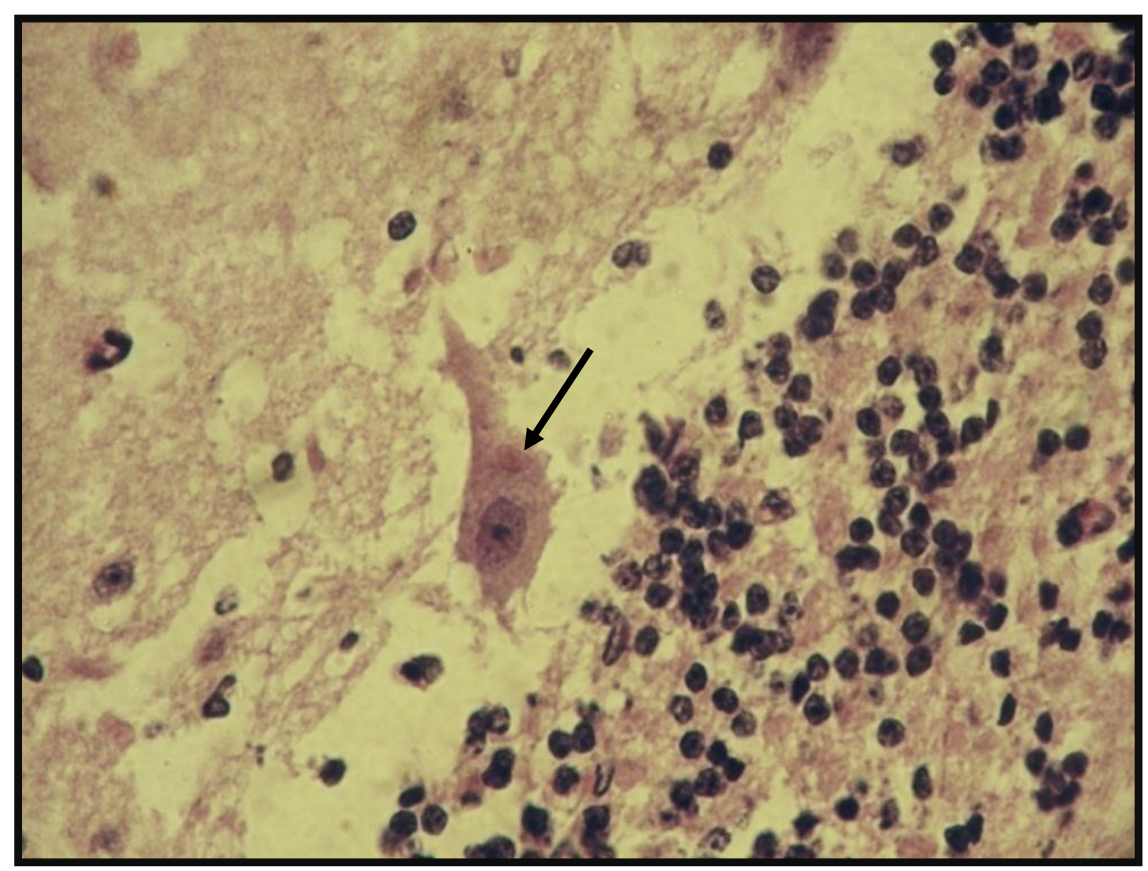

Figure - 9: Histopathological section in cerebellum of rabid ewe showed degenerated Purkinje cell containing intracytoplasmic, acidophilic and oval shaped inclusion body ( Negri body arrow), with mononuclear cells infiltration within granular layer. (H \& E stain X40).

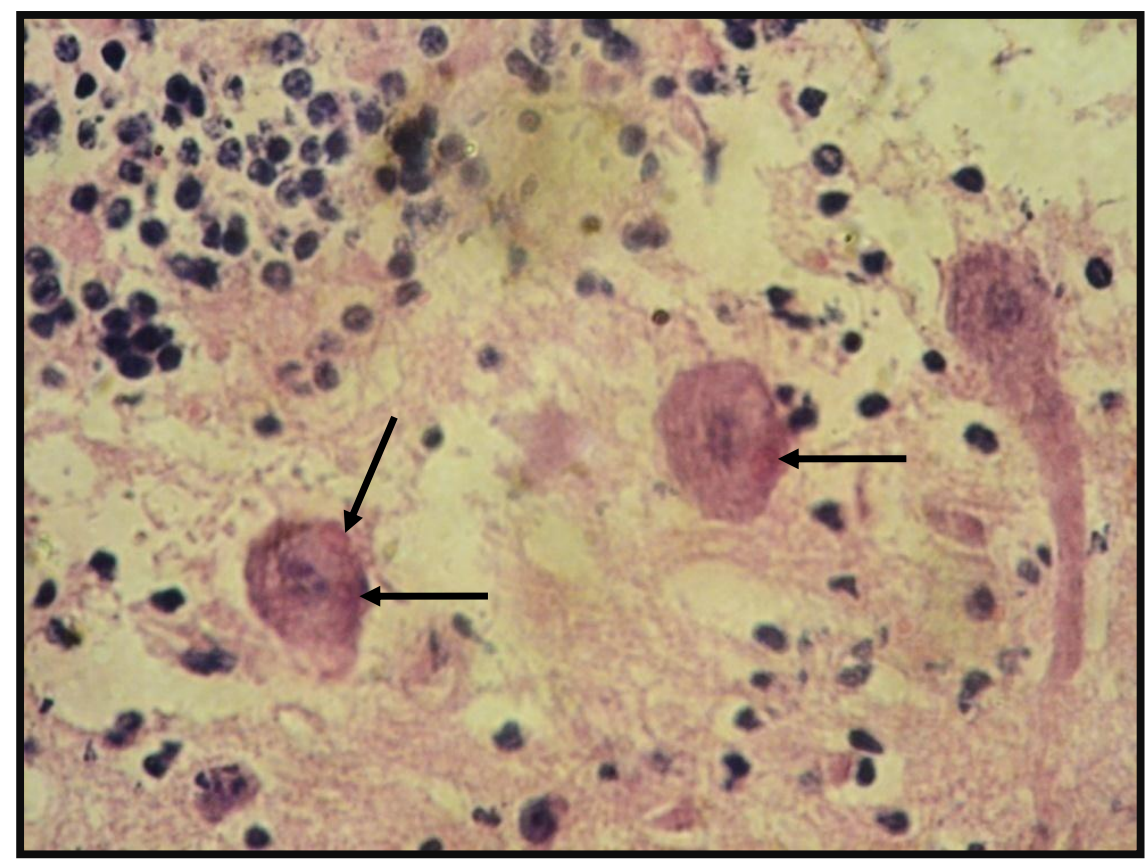

Figure - 10: Histopathological section in cerebellum of rabid ewe showed intracytoplasmic, acidophilic and round to oval shaped inclusion bodies (Negri bodies - arrows) within degenerated

Purkinje cells, and mononuclear cells infiltration within granular layer. (H \& E stain X40). 


\section{References}

1. Heymann D (2004). Rabies In: Control of Communicable Diseases Manual. $18^{\text {th }}$ Edition. Washington, DC ed. American Public Health Association: 438 - 47.

2. American Veterinary Medical Association. (2009). Back grounder: Rabies. No.7.

3. World Health Organization - WHO. (2010). Rabies epidemiology. http://www.who.int/rabies/epidemiology.

4. Tomas E Kienzel (2007). Rabies In: Deadly Diseases and Epidemic. Info base Publishing USA.

5. Rupprecht C and Shlim D (2009). Rabies In: Yelow Book chap.2 (49).

6. Centers for Disease Control and Prevention (CDC). Human Rabies prevention--United States (1999). Recommendations of the advisory committee on Immunization Practices (ACIP). MMWR 48( RR-1).

7. Shankre B P (2009).Advances in the diagnosis of Rabies.Vet. World. 2(2): 74 87.

8. Gerard JN Defaria DL Chanona Vilchi JG and Zhang y (2005). Molecular detection of Rabies encephalitis and correlation with cytokine expression. Modern Pathology. 18: 62 - 67.

9. Centers for Disease Control and Prevention (CDC). (2009). Rabies Diagnosis. Public Health Matters. I (800) CDC - INFO: 232 - 4636.

10. Luna LG (1968). Manual of Histologic Staining Methods of the Armed Forces Institute of Pathology. $3^{\text {rd }}$ Edition. The McGraw - Hill Book Company. New York USA.

11. Hanlon A (1999). Protocol for postmortem diagnosis of rabies in animals by direct florescent antibody testing: minimum standard for rabies diagnosis in United States. JAVMA. 215: 1444 - 1446.

12. Durr S Naissengar S Mindekem R Diguimbye C Niezgoda M Kuzmin I Rupprecht C and Zinsstag J (2008). Rabies diagnosis for developing countries. PLoS. Negl. Trop.2 (3).

13. OIE - Terrestrial Manual. (2008). Rabies. pp: 343 - 324.

14. Lembo T Niezgoda M Villa A Cleaveland S Ernest E and Rupprecht C (2006). Evaluation of the direct, rabid, immunohistochemistry test for Rabies diagnosis. Emerging Infectious Diseases. 12 (2): 310 - 313.

15. Jackson A and Wunner W (2007). Rabies $2^{\text {nd. }}$ Edition Elsevier Inc.London UK.

16. Love S and Willy CA (2002).Viral Diseases In: Greenfield's Neuropathology. $7^{\text {th }}$ Edition. By: D. I. Graham and P. L. Lanots, eds London UK. Pp: 1 - 105.

17. Negri A (1903a) Bietrag Zum Stadium der Aetiologie der Tollwuth. Zeitschrift fur Hygiene und Infektionskrankheiten. 43: 507 - 528.

18. Negri A (1903b). Zur Aetiologie der Tollwuth. Die diagnose der Tollwuth anf Grund der Meuen Befunde. Zeitschrift fur Hygiene und Infektionskrankheiten. 44: 519.

19. Babes MV (1892). Sur certains caracteres des lesions histologiques de la rage. Annales de L Institut Pasture. 6: 209 - 223. 
20. Fu Z and Jackson A (2005). Neural dysfunction and death in Rabies virus infection. Journal of Neurovirology. 11: 101-106.

21. Burton E Burn D and Opatowsk M (2005). Rabies encephalomyelitis: clinical, neurordiological, and pathological finding in transplant recipient. Archives of Neurology. 26: 873 - 882.

22. Iwasaki Yand Tobita M (2002). Pathology In: Rabies by: A C Jackson and W H Wunner Edition. San Diago Academic Press USA. Pp: 283 - 306. 